\title{
SPECIFIC FEATURES OF INTRODUCING THE COMPONENTS OF INCLUSIVE EDUCATION IN HIGHER EDUCATION INSTITUTIONS WHEN TRAINING PROFESSIONAL COMMUNICATION IN ENGLISH
}

\author{
Yuliana N. Antyufeeva \\ antyufeeva_1976@inbox.ru \\ Natalia E. Bulaeva \\ natbulaeva27@mail.ru \\ Tula State Lev Tolstoy Pedagogical University (Tula, Russia)
}

\begin{abstract}
This paper is devoted to the problems of inclusive education in terms of training professional communication in English. The objective of this paper is to study and analyze specific features of inclusion from a methodological perspective. The authors sum up various approaches to the definition of inclusion and reveal that the main requirements to the teaching staff include professional attributes, competence and some general criteria. All this can significantly affect the process of teaching handicapped students. Language training syllabus components are also taken into consideration, the described teaching strategy represents an antipode of traditional educational form called "flipped classroom" pedagogical technique. The authors study the technique application from different angles showing advantages and disadvantages that are intrinsically linked with the issues of teaching quality improvement. All the above mentioned proves the fact that foreign language teaching within the framework of inclusive education has to represent the form of componential complimentarity interconnected with the professional language theory towards individual needs and the system of values of the handicapped students.
\end{abstract}

Key words: inclusion, handicapped students, professional competence, "flipped classroom" pedagogical technique.

\section{INTRODUCTION}

Nowadays in modern society an attention is increasingly paid to an issue of teaching the handicapped children not only at school but in higher education institutions as well. Joint education of students with different physical capacities or, in other words, inclusive education, is one of the ways of integrating the handicapped students into an area of professional education. Inclusion is globally accepted and is considered worldwide as the most humane ideology that provides for excluding any form of handicapped students discrimination. Thus, modern institutions of higher education are focused on adapting the educational system to special needs of handicapped students with their objectives of getting a high-quality higher professional education and being settled in life. The key feature of such educational establishment is the search for the new approaches, methods and modes of study and their implementation in the interests of special students [Osikova \& Alekseeva, 2017, p. 21]. This paper is devoted to the problems of inclusive education in terms of training professional communication in English. The aim of this paper is to study and analyze specific features of inclusion from a methodological perspective.

\section{LANGUAGE TRAINING METHODOLOGY OF HANDICAPPED STUDENTS AND ITS ASPECTS}

Language training methodology is governed by its own laws due to which it is generally accepted to divide all training concepts into didactic and methodological. General didactic aspect of a language training syllabus in an institution of higher education must be surely a 
result-oriented one. Competences developed in the process of training are to be considered as scheduled goals [Maslennikova \& Yudin, 2008]. Setting forth a goal on the basis of the results shall allow the students to realize and understand in a better way what exactly they are ready to do. Goal achievement in this case is the basis for forming and development of a specialist, thus, it will be quite logical to make a language training syllabus taking into account the requirements imposed by a professional activity and contributing to the attainment of professional communicative competences.

Therefore, first of all it is necessary to guide the handicapped students to conscious mastering of activities involving language material and, primarily, grammatical one. Speaking about the specific features of teaching foreign languages in this case, from our point of view it is appropriate to use the native language as a support, since in this situation the principle of consciousness will provide for exclusion of mechanical development of skills and expertise with the students. The main way to bridge the gaps here is the communicative strategies, i.e. the strategies that are used by people in their native language without any special training. For example, a return to the aforesaid, a periphrasis or a change to a common word, a pronoun, a synonym; it is important to teach the handicapped students to use these strategies in learning a foreign language and to create an environment where communication is a necessity.

\section{NECESSARY TEACHING STAFF REQUIREMENTS RELATED TO INCLUSIVE EDUCATION}

Equally important feature in the process of inclusive education is, of course, the information level, the expertise and professional competence of the teaching staff.

Nowadays in a modern society the requirements to a teacher, to his or her professional skills and personal attributes have changed greatly. However, the level of professional competence of teachers, the level of maturity of such attributes as empathic ability, pedagogical tact, creativity, communicative skills sometimes do not meet in the full scope the requirements of the educational services consumers [Maslennikova \& Yudin, 2008].

Education is the main value and getting an education is believed to be a duty of any person. It is so versatile that it also implies an ability to adapt to real-life situations, and a process of building up a character facilitating the improvement of one's personal qualities such as rationalism, sensitiveness and intelligence. There is no doubt that the 21 st century is characterized by the emerging of multiculturalism due to the onrush of industrialization, globalization, urbanization and disintegration of a family system. This century is called by psychologists a century of stress and tension. And since an education is an instrument for the development of cognitive abilities, tolerance and understanding, its main objective is to prepare the young generation to meet the problems of globalization in the society. In this context the educational institutions and a teaching staff bear a heavy load of responsibility in the area of forming a student's character where professional culture of a teacher, i.e. his or her professional competence, becomes an essential feature.

Competence of a teacher is usually associated with high expertise that is directly connected with efficiency of the teacher's and the student's work. There are two generally accepted definitions of competence in education. From a theoretical point of view, competence is a cognitive structure contributing to promotion of certain behaviour patterns. From a practical point of view, competence covers wider range of skills, expertise and behaviour patterns; it is a kind of a dynamic process of mastering and upgrading the job-related experience leading to the development of personal professional behaviour and gaining of professional experience [Yakovleva, 2002]. This definition includes knowledge, expertise, skills, positions, metacognitions and strategic thinking and suggests that a teacher makes conscious and intentional decisions.

The profession of a teacher, without a doubt, presupposes an availability of intellectual 
outfit, a skill to gain various skills and expertise, an ability to discriminate between a desire to work and self-interests, regular and systematic promotion of attained results, clear professional arrangement and an ability to learn.

\subsection{Teacher's professional attributes}

Professional attributes of a teacher in their turn predetermine those features that are clearly identified and are the key ones to ensure efficient training. These qualities specify the needs and requirements of training. They provide for the development of specific values, views as well as for mastering the skills necessary for a teacher to take one or another decision in a daily work. Let us consider in detail which attributes are the most in-demand.

1) An ability to work in a team. Teachers should have excellent abilities of interpersonal communication to share knowledge, ideas and experience. They must be ready to support their colleagues, accept criticism and take a piece of advice from others as well as be partners with students, parents, and colleagues in the educational process.

2) Commitment to the job. A priori, teachers devote themselves to teaching, work in the interests of students and are eager to take a challenge and make something that is important. A teacher is dedicated to educational, personal, social, moral and cultural development of his/her students, calls them for an anxiety for knowledge throughout their life, for being active members of the society.

3) An ability to communicate. Any teacher is required to find inside him-/herself such a quality that will contribute to the creation of a positive attitude in students. In this case it is important to express his/her thoughts and ideas using linguistic means appropriate to the situation and audience.

4) Morality. A teacher has to respect the rights of others, be consistent and impartial, understand the principles of social justice and demonstrate them accordingly when making one or another decision.

5) Creativity. A teacher always has to approach a problem creatively, be able to take a risk in order to find a fresh solution that will allow making the educational process more efficient, be resourceful in the development of new programmes.

6) Inclusiveness. In an attempt to study current educational, physical, emotional, moral and cultural requirements of students, the teaching staff, primarily, has to take care of the students, be able to react to the barriers that hamper a slowdown of the educational process.

7) Positiveness. A teacher always has to interact with the public in a constructive way, demonstrate flexibility in a constantly changing rhythm of work, think critically and be able to adopt innovations. In this context a teacher is a defender of his profession.

\subsection{Teacher's professional competence}

Undoubtedly, there are a lot of factors influencing the quality of training and, of course, among them there is a professional competence of a teacher that includes basic and pedagogical knowledge, proficiency in training techniques and in the subject, experience and status.

A fact which has obtained general recognition is that any educational institution has to maintain moral values and to ensure efficient training. A school is a cradle of a nation and teachers are the builders of the future. The role of a teacher in the development of a society is indisputable as well as heavy is the burden of responsibility. A well-known saying goes that one cannot become a teacher, one has to be a born teacher. Here it is worth mentioning that such a statement is still topical in a modern world where the main challenge for the teacher is to solve a problem of what is to be taught and how this is to be taught. In this connection an issue of professional competence is of crucial importance.

Professional competence of a teacher has a critical influence on the formation of the student's personality. A teacher must be a source of information that is always in demand 
[Belikov, 2010].

Professional competence is certainly understood as an intellectual potential of a teacher which is directly interconnected with an ability to assist, guide and give recommendations to students in order to achieve a desired result. A teacher who considers his/her job as a profession cannot be driven by financial benefits, first and foremost it is a commitment to job and service to the educative mission. Thus, a teacher's competence is a synergy of professionalism (special, methodological, psychological-pedagogical background), creativity (creativity of relations, optimum use of means, approaches and methods of teaching) and art (an art of acting and an oratorical skill) [Maslennikova \& Yudin, 2008].

As for the personal features of a teacher, they manifest in pedagogical skills, e.g. gnostical, constructive, communicative, organizational, predictive and special.

Gnostical skills are a group of skills contributing to the study of a child, his/her age and individual peculiarities, personal qualities, relationship with people of the same age, adults, degree of emotional well-being, community as a whole, capabilities of a family to bring a child up. Studying of a student represents the basis for understanding of his/her inner world by a teacher. The use of gnostical skills gives a teacher an opportunity to explain the reasons of behaviour, see the ways of improving upbringing and educational processes, modify common goals and objectives of upbringing with regards to a particular group of students keeping in mind all the specific features of their development.

Constructive skills are represented by work planning, making of lesson summaries, scripts, festive occasions, etc.

Communicative skills are required in establishing pedagogically expedient relations with a student or with a group of students, with parents, colleagues, the management of an educational institution. They are important to enable a teacher to quickly find a contact with various people in various situations, to find a common ground as well as for tolerance and optimism. Arrangement of communication requires from a teacher to know the techniques of communication establishment: ability to speak well, clear articulation, regular breathing, body language, body control, psychological state control, proficiency in intoning to express various feelings.

Organizational skills include mobilization, informational, educational and orientation skills. Mobilization skills imply drawing the students' attention and development of sustainable interest in them towards learning, work and other types of activity, forming demand for knowledge. Informational skills imply presentation of educational and cognitive information and forming in students the habits of self-reliant search for it. Educational skills, first of all, represent the creation of conditions contributing to the development of cognitive processes, emotions and will; stimulation of cognitive self-reliance and creative thinking; development of individual peculiarities; implementation of individual approach towards each student. Orientation skills are aimed at forming the system of values and morality in students, implanting a sustainable interest in learning and cognitive activity, organizing joint creative activity to develop socially-significant personal traits.

Predictive skills may be defined as setting the pedagogical goals and objectives, selecting the ways of their achievement, forecasting the results, possible deviations and adverse events, defining the stages of pedagogical process, pedagogical forecasting. This group of skills may be supplemented with the reflective skills. Reflection is not just the self-knowledge and self-understanding of a teacher who is the subject of pedagogical activity. It is also an exploration of how the others know and understand his/her reflection, personality, emotional reactions. It is an ability to carry out self-analysis of the performed work, evaluation of the results and their correlation with the goal.

A set of special skills include the specific skills like the ability to state something in different ways, the ability to self-training including search and creative processing of 
information useful for training as well as its direct use in pedagogical activity and many other things. The more such special skills a teacher has, the more interesting, informative and efficient the educational process becomes.

Therefore, the power of pedagogical influence is mostly determined not by its direction but by who and how influences. This exactly explains why the basic factor of educational process efficiency is the teacher's personality. To effectively influence the students, to come into interaction with them, to encourage their independent activity a teacher needs to have a deep knowledge of laws under which the process of knowledge and skills expertise assimilation is performed and how attitude towards people and world phenomena is formed. A teacher must learn how to use this knowledge in practice, gain experience, craftsmanship and the art of their best application.

\subsection{General criteria of teachers' professionalism}

As far back as the 19th century, K.D. Ushinsky pointed out the importance of the impetus and desire for self-improvement, self-development, self-realization, self-training for a teacher, saying that a teacher lives as long as he/she learns; as soon as he/she stops learning, a teacher dies in him/her [Osikova \& Alekseeva, 2017]. This paramount idea was emphasized by V.A. Sukhomlinsky, P.F. Kapterov, P.P. Blonsky, A.S. Makarenko and other scientists of great mark.

Professor Andy Goodwin defines 8 common criteria of a foreign language teacher's professionality: knowledge of the language, professional self-determination, ability to plan and analyze, objective evaluation, keeping records, relationship with students and colleagues, personal qualities and understanding of the context of the situation. The necessary personal qualities according to him are: self-criticism, tolerance, sociability, interest in the subject (job), desire for innovation and self-perfection. Nevertheless, the professor believes that it is naïve to think that all the above-mentioned qualities will be identically revealed in different people (teachers), all features are purely individual and consequently, unique. Only goals and objectives may be common in teaching a foreign language, the ways achieving them are infinitely various [Goodwyn, 2016].

In his turn, academician Ali Dincer, upon completion of his Research on Multiple Intelligence Profiles in 2013 supplemented the list of personal qualities of a foreign language teacher by adding availability of social influence, namely, motivation and enthusiasm, flexibility, desire for respecting the students' opinion and meeting their requirements, creation of antistress environment in the lesson [Dincer, 2014].

It is worth mentioning that a foreign language teacher must be a good listener and a keen observer. Teaching a foreign language is in any case connected with some nervousness of students, since teaching is done not in the mother tongue. Accordingly, the teacher's objective is to be always amicable and helpful, he/she must constantly follow up the students to understand their needs and overcome difficulties in time. Observation may prompt the teacher to orient him-/herself in one or another situation and to use proper verbal and nonverbal means of communication.

Background knowledge also takes not the last place in the list. Fundamental knowledge of history and culture of the studied language is essential in the work of a foreign language teacher. This knowledge is the basis of linguistic-cultural competence of a teacher that, in its turn, may become the starting point in planning and choosing the strategies and methods in the process of foreign language teaching at school.

Future development of education put on an agenda the issue of continuous pedagogical education and self-perfection. An ability to "create one's own self" according to social and moral ideals where professional competence and rich spiritual life would become the natural conditions of a human life. 
That is why the only recommendation that may be given to all teachers is the improvement of their own skills, personal features and self-education. Only in this case there is a real opportunity to become a good and competent teacher as the efficiency of professional activity directly depends on development of personal qualities of a teacher.

Nevertheless, currently in the society there is an opposite point of view on the inclusion: on the one hand, a loyalty to the introduction of this approach is demonstrated; on the other hand, there is a flat rejection of the fact of teaching handicapped children jointly with those having a good health. Consequently, the teachers do not have enough practical skills and abilities to be used in solving specific issues both in professional activity and in life. Therefore, it is necessary to take into account the fact of pedagogical staff retraining, which, in its turn, will influence and assist in distributing state-of-the-art technologies of inclusive education and training techniques in general [Akhmetzyanova et.al., 2015, p. 17].

Nowadays, the society specifies some other requirements to the specialists, and within this context the competition on the labour-market grows, including the handicapped, who require development of abilities to be continuously self-educated to a greater extent. An evident obstacle for such young specialists is the mobility, thus, introduction of information technologies into the educational process becomes of crucial importance. They are to a greater degree helpful in implementing an interdisciplinary approach in foreign language teaching [Inclusive education, 2017, p. 349].

\section{LANGUAGE TRAINING SYLLABUS COMPONENTS FOR HANDICAPPED STUDENTS}

One of the tools to introduce information technologies is, undoubtedly, the web space including its English-speaking segment. Consequently, the English language is of primary importance in the cultural development of the personality, its socialization, imparting of communication skills and broadening the mind in general [Akhmetzyanova et.al., 2015, p. 18]. Certainly, handicapped students may face difficulties in studying a foreign language and the teacher's objective is to highlight the value of the ability to communicate in English as one of the conditions of professional self-realization in the modern world.

Any launch of thinking processes in students will facilitate their constant creative research, will teach them to analyze information, build connected consistent statements, communicate and express their opinion in a correct way. Because active methods of work are exactly aimed at creation of a favorable motivational and emotional environment at foreign language lessons, this way of teaching will, undoubtedly, encourage a development of sustainable interest towards mastering intercultural competence which is a part of professional competence. All the above mentioned components of professional success will lead the students, future specialists towards a more fruitful and successful dialogue with foreign colleagues.

Self-analysis and self-appraisal are considered in the Russian and the world literature as the main tools for professionalism development and the main psychological controllers of professional growth.

Therefore, the components of a language training syllabus in an institution of higher education are to be classified as follows:

- communicative situations reflecting everyday requirements;

- communicative situations of personal nature;

- social and political situations;

- situations of professional communication.

Thus, the educational process represents a joint activity of teachers and students in which the former share their knowledge and the latter assimilate it. So, it is a kind of a social process motivated by the public needs and allowing the students to actively react according to 
the situation.

Correspondingly, it is possible to develop various types of tasks depending on the goals.

It is quite expedient to introduce a modular arrangement of a foreign language teaching which is understood as work with specific teaching information. For example, one of the training stages may include several modules, each containing a professionally-oriented authentic text, set of exercises, check unit and a mini-research or a project on the studied topic. Thus, students will be able to undergo a kind of a short-term special professional course of a foreign language based on professional requirements.

Predominantly, such means are used in this environment as: video and audio records, various theme-based web sites, simple authentic texts - the main point is to correspond to the level of foreign language knowledge of the handicapped students. The preparatory stage in this case is of primary importance, both on the part of a teacher and on the part of a student. Auxiliary handout materials require a lot of effort and working hours, this type of work is considered to be the most labour-intensive since it requires thorough development and description. It should be also noted that informational simplicity is important in the process of working with an authentic English text. The most popular tasks are considered to be the webquests, they have a clear structure and contribute to development of the skills of searching the web space for information [op. cit., p.25]. Moreover, this type of activity may be offered for individual and group work. Working with the Internet, undoubtedly, assists in activating colloquial speech in English and at the same time e-mail resources may be used to develop the skills in the written language. One more simple and accessible shell is the Moodle where a teacher may not only organize but monitor an activity of handicapped students as well.

\section{5. "FLIPPED CLASSROOM" PEDAGOGICAL TECHNIQUE}

It is obvious that the issues of inclusive education are to be solved by the introduction of new forms, methods and techniques of training. One of the latest trends in this area is the "flipped classroom" pedagogical technique.

The "flipped classroom" pedagogical technique, as many other pedagogical innovations, came to Russia from the experience of American teachers. The founders of this technique are Jon Bergman, a high school teacher, and Aaron Sams, a teacher of chemistry. Jon Bergman was always interested in the way of the best usage of face-to-face communication between a teacher and a student in the lesson. Having an experience of in-class teaching, online teaching and their combination, Aaron Sams stands for a learning environment, in the centre of which there is a student who asks questions and where students have an opportunity to show their understanding of the material in the form accessible for them [Bergmann \& Sams, 2012].

The "flipped classroom" is described in pedagogical literature as an antipode of the traditional educational form where students get acquainted with new material for the first time being beyond the classroom, usually, through reading or watching video lectures, and the classroom time is used for more sophisticated brain work - using the obtained knowledge to solve problems, discuss and analyze.

The said technique is aimed at reorientation of the teaching methods at high school and higher education institutions. Certainly, there are many strategies that may fit into this category but most of them represent not more than one of the teaching methods based on a combination of online and offline components. It is worth mentioning that the online video component in the 21st century became more accessible than ever; it is possible to record lectures, presentations, illustrations to practical exercises that definitely attracts an attention towards a "flipped classroom" technique in general due to the fact that the goal of this technique is to upgrade the teaching methods via efficient introduction of the new technologies.

An opportunity to increase an interaction between the teacher and the students is 
primarily based on diversified use of the class hours. For instance, a traditional lecture may be preferably arranged in the form of practical exercise in order to better understand the needs of the students, to find out an extent of additional support they require while studying some particular material. A lecture itself becomes an online teaching format; the students can watch recorded lectures at home that provides for more efficient use of the face time of the teacher and the student at the lesson. For example, the students are offered to watch a lecture at home, to make a summary for discussion of the material and, perhaps, to discuss it online in mini groups just prior to the lesson. An experience shows that the use of such teaching format makes the students more prepared and activity in the lesson becomes more efficient.

Such technique allows devoting the class hours to broadening and assimilation of the material by means of joint training and discussion. Basically, routine homework, normally to be done at home, is done in the lesson, and a lecture, traditionally delivered in the lesson, is watched and studied at home - that is the basis of the "flipped classroom" strategy.

Thus, if to consider the idea of the "flipped classroom" from the point of Blum's taxonomy, it will come out that the initial levels of cognitive activity (acquiring of knowledge and comprehension) are realized by the students outside the classroom and in the lesson, where the students are supported by other students and teachers, main attention being focused on the higher levels of cognitive activity (application, analysis, synthesis and/or evaluation) [Anderson \& Krathwohl, 2001].

Giving students an opportunity to use their new knowledge in the classroom in an environment of immediate feedback from other students and the teacher will assist them in correcting wrong ideas and arranging their new knowledge in such a way that they can have an easy access to it in the future. Moreover, a direct feedback inherent in a "flipped classroom" technique, in our opinion, will help the handicapped students to approach the training process more consciously.

Such metacognitive approach towards training, as John Bransford sees it, may help students to take control over their training by means of setting forth training goals and monitoring the progress in reaching them [Bransford et. al., 2000, p. 18].

Theoretical justification of the right of existence of this technique and its introduction into the educational process may be found in "How People Learn" by J.D. Bransford, A.L. Brown and R.R. Cocking. To develop a research competence, students must:

- have a solid knowledge base;

- understand facts and ideas in the context of conceptual framework of a subject;

- arrange their knowledge in such a way to ensure their timely application [op. cit, p. 16].

An experience of such technique application shows that it is vital not only for students who missed classes due to various reasons but also, curiously enough, for the students who did not miss the class. They use online material mainly to revise, repeat and better understand the material given in the class.

This technique gives an opportunity to drastically review the idea of efficient use of the class hours.

It should be noted that the first trial of such form of work caused confusion with Russian students who got used to listening to an exact material at a lecture, and initially the whole thing was not of a major success. However, in the course of time questions asked by them became deeper that demonstrates their endeavor to get to the heart of the matter.

A "flipped classroom" technique ensures easy revealing of wrong understanding of scientific concepts by some students and provides for correcting them at the right moment.

Work in the class has also changed. In a standard lesson "smart" advanced students are more active and "ordinary" students prefer to stay in the background. In the conditions of the "flipped classroom" the questions start to come from "ordinary" students who try to sort out 
the complicated issues, meanwhile "smart" students get more freedom for self-learning. The main idea of a "flipped classroom" technique consists in a fundamental change of general educational approach: if before students learned the new material only at a lesson, now with the use of a "flipped classroom" technique a teacher presents the materials of the lesson to the students, records a video, announcing the key points of the future lesson, gives particular instructions beforehand. The lesson itself becomes the time for working through the issues, discussion of complex concepts, debating; the students become active participants of the educational process and, consequently, the technique of collaborative learning is actively used. It is getting obvious that a new arrangement of work improves the relations between the colleagues, increase motivation to learning and activates the educational process that in the framework of inclusive education will be the huge advantage.

However, this strategy implies not only training of students but motivation of teachers to use this pedagogical technique, i.e. to offer an alternative form of improving accessibility of the syllabus. Recording of 4-6 minute videos is a real challenge for a teacher: how to explain a concept in a clear, compact digestible bite. As for the materials and videos which are offered to the students prior to the class, they require special elaboration. It is not a chapter of the book, lecture notes, set of exercises. It is quite a different material in terms of the form and content requiring high pedagogical excellence from the teacher. The concept of a future lesson is to be presented in a clear, compact and brief way. Every small detail counts: pace, examples, video picture, figurativeness of presentation of the new topic. The goal of such annotation of the upcoming lesson is not to investigate every detail but to tune to the required mode, to arouse interest and questions.

An experience of such technique application shows that it is impossible to entirely exclude a lesson as a face-to-face communication with the students, moreover, it is not worth trying, since the materials given to the students prior to the lesson for familiarization contain not so much the answers to the questions but rather encourage thinking, arouse questions, lead to deeper understanding of the core of the problem. When developing the materials and recording the video announcing the lesson, the teacher must take into account all the aforesaid and demand from the students to come to the class with the questions. Thus, the main objective of a "flipped classroom" technique is drawing the students into active training in two directions - acting and thinking of what they are doing.

\section{TECHNIQUE PROS AND CONS}

Let us examine the main advantages of this technique for teaching the foreign language of professional communication in a higher education institution within the framework of inclusive education. Firstly, due to the increasing role of self-testing in learning and development of interaction skills, a handicapped student is provided with an opportunity to watch and listen to the lecture several times, pause, note down the questions and discuss them with the teacher that results in the narrowing of the gaps in the students' knowledge; they communicate easier with each other which definitely invokes the feeling of self-sufficiency. One more important point is that it is possible to come back and review any aspect of training that in the best way makes up the lack of such important resource of training as time. Secondly, accessibility of the material, both in terms of its availability and in terms of its understanding. Updating the design, structure and format of the training course allows students to review their attitude to training, increase their motivation, set proper expectations and goals and monitor their achievements. Such format is certainly efficient in case a student misses a class. Thirdly, time required for doing homework is decreased.

Nevertheless, such strategy features a number of drawbacks which are to be taken into account in introducing it into the inclusive educational process. Among them is the Internet access. In general, it is available for everybody but some technical problems may occur causing 
some difficulties for handicapped students to get prepared for the lesson. Furthermore, introduction of this technique envisages purposefulness and responsibility of students and teachers, and this is a long-term process. Moreover, a number of students in the group is not the least of the factors that may directly influence the process of interaction between students and teachers in the classroom.

One more problem that may arise is that many courses upon upgrading start to focus on the introduction of a large portion of projects into educational process and it is necessary to avoid pedagogical extremes in terms of a number of projects and their content.

Also there is a risk that the "flipped classroom" may be interpreted as one more aspect in the false confrontation between a teacher and technology. A disseminated myth of a "flipped classroom" technique is that it is just the use of technologies and video instead of traditional lectures. Jon Bergman and Aaron Sams, who promoted this term, assert that in this case the active component of education is of primary importance; it is the one that has the maximum potential for improving the quality of education, and it does not always presuppose the prerecorded video lectures [Bergmann \& Sams, 2012].

However, it seems quite obvious that such technique is a good means of a teacher's self-development. Creation of training videos is not only a powerful tool in the development of the course content; it also facilitates the increase of quality of pedagogical excellence of some teachers by means of joint use of resources.

Thus, the main positive features of a "flipped classroom" technique are:

1. An opportunity to get the first impression and information about the topic and the content of the lesson beforehand. The way of getting familiar for the first time may vary from simple reading of the textbook chapter (at the initial stage of using this technique) to watching video podcasts or video clips (which are to be prerecorded and placed to ensure free access for the students).

2. Motivating students to get prepared for the lesson. In any case the main stimulus for students to learn is the marks and scores. The "flipped classroom" technique demands to evaluate not an attempt to do a written or creative task but exactly task fulfillment.

3. Evaluation and correction of students' understanding of the lesson material. Preliminary tests, quizzes, written exercises may help both the students and the teachers to specifically define the points that require clarification and special attention. Moreover, many types of activities used in the lesson (for example, discussions) may serve as unofficial tests of students' understanding.

4. Development of a higher level cognitive activity in a lesson. Since students got the basic knowledge outside the class, they must use the classroom time to extend their understanding and improve their skills in using the new knowledge.

Thereupon, it seems to us quite appropriate to think about introducing this strategy into the process of inclusive education especially in the institutions of higher education where the connection between the language and professionally-oriented knowledge is lost thus leading not only to the loss of interest in foreign language learning but to understanding of the discrepancy between the used means and objectives to be achieved. That is why, in our opinion, it is necessary to combine traditional and alternative strategies in teaching the foreign language of professional communication allowing to develop the skills of carrying joint activity and to understand necessary social and cultural reality inside which a process of forming a mature linguistic personality is performed.

\section{QUALITY IMPROVING PROBLEMS OF TEACHING HANDICAPPED STUDENTS IN HIGHER EDUCATION INSTITUTIONS}

Modern society requires from a person the knowledge of a foreign language which 
represents a specific link of cultural and social relations, interpersonal and professional communication, and efficiency of intercultural dialogue depends on the extent of the student's motivation to get the knowledge and master the foreign language. In this context it is exactly the motivation which is to be given the proper place within the framework of professionallyoriented foreign language lessons. Motivation is a kind of an accelerator, the aggregate of reasons facilitating the propagation, in this case, of knowledge in a particular actual situation [Federal state educational standard of higher education].

Thus, if the content of a subject is properly selected and arranged with the use of modern technologies, then the issue of increasing academic motivation of handicapped students in the process of teaching the foreign language in a higher education institution will be, without a doubt, successfully solved.

However, the technique used in teaching a foreign language is mainly based on professionally-oriented monological educational texts and does not fully satisfy the practical objectives of inclusive education. In the process of forming necessary speaking and reading skills, additional authentic training materials of linguistic-cultural and social-cultural orientation are not used. Such gap definitely requires reconsideration of the issue of improving the quality of education in terms of competency building approach.

Firstly, it is necessary to take into account the fact of absence of continuity between schools and a higher educational institution. So it is quite difficult for a university professor to solve the issue of levelling the foreign language grounding of handicapped students and to bring it to the required level.

Secondly, for efficient setting of goals and objectives for teaching a foreign language in a higher educational institution it is necessary to keep in mind the requirements imposed by social and economic changes in the society and industry that are to be revealed later in the requirements to a specialist's qualification.

The study shows that the initial training level of handicapped students proves the necessity to upgrade the forms of inclusion. A lack of practical usage of corresponding methods of teaching a foreign language within the framework of professional activity in the modern informational environment is determined by an absence of demand for foreign language communication in the work of handicapped specialists.

\section{CONCLUSION}

The goals of foreign language training syllabus preparation are to be correlated with the goals of specialist training with reference to the requirements to their professional activity. Teaching a foreign language within the framework of inclusive education must reflect the fact of complimentarity of the components of educational activity, their interconnection within the framework of the professional language theory with respect to individual needs and system of values of handicapped students. Thus, qualitative and quantitative progress of students is based on the established priorities in the conditions of joint communicative activity, partnership and active interaction between the teachers and students as well as on individual approach to the development of the student's personality, capable of transformation and adaptation in educational professional environment which is typical of handicapped people.

\section{REFERENCES}

1. Akhmetzyanova, A.I., Artemeva, T.V., Kurbanova, A.T., et al. (2015). Inklusivnaya praktika $v$ vysshey shkole [Inclusive practice in higher educational institutions]. Retrieved from https://kpfu.ru/staff_files/F1150883314/Inkljuzivnaya_praktika_v_vysshej_shkole.p df (accessed: 2 May, 2019) (in Russian). 
2. Anderson, L.W., \& Krathwohl, D. (2001). A taxonomy for learning, teaching, and assessing: a revision of Bloom's taxonomy of educational objectives. New York: Longman.

3. Belikov, V.A. (2010). Obrazovanie. Deyatel'nost'. Aktivnost' [Education. Activity. Personality]. Moscow: Akademiya Estestvoznaniya (in Russian).

4. Bergmann, J., \& Sams, A. (2012). Flip your classroom: reach every student in every class every day. Washington, D.C.: International Society for Technology and Education.

5. Bransford, J.D., Brown, A.L., \& Cocking, R.R. (2000). How people learn: Brain, mind, experience, and school. Washington, D.C.: National Academy Press.

6. Dincer, Ali. (2014). Antecedents and Outcomes of Self-Determined Engagement in Turkish EFLClassrooms: A Mixed Method Approach (Unpublished doctoral dissertation). Atatürk University,Erzurum, Turkey.

7. Federalny gosudarstvenny obrazovatelny standart vysshego obrazovaniya. Uroven' vysshego obrazovaniya - Bakalavriat. Napravlenie podgotovki 38.03.01 "Ekonomika" [Federal state educational standard of higher education - Bachelor's Degree. Specialization 38.03.01 "Economics"]. Retrieved from http://gosvo.ru/uploadfiles/fgosvob/380301.pdf (accessed: 5 May, 2019) (in Russian).

8. Goodwyn, A. (2016). Expert Teachers: an International Perspective. London: Routledge, Falmer, December

9. Inklyuzivnoe obrazovanie: preemstvennost' inklyuzivnoi kul'turi i praktiki [Inclusive education: succession of inclusive culture and practice]. (2017). Retrieved from http://www.inclusive-edu.ru/wp-content/uploads/2017/06/maket4.0-v-pechat.pdf (accessed: 12 May, 2019) (in Russian).

10. Maslennikova, V.Sh., \& Yudin, V.P. (2008). Pedagog i kul'tura [Teacher and culture]. Kazan (in Russian).

11. Osikova, L.N., \& Alekseeva, O.P. (2017). K voprosu o povyshenii motivatsii studentov pri izuchenii inostrannogo yazika $v$ vuze inklyuzivnogo obrazovaniya [To the question of student motivation improvement when foreign teaching studying at the institution of inclusive education]. Retrieved from http://www.publishingvak.ru/file/archive-pedagogy-2017-2/20-osikova.pdf (accessed: 8 May, 2019) (in Russian).

12. Yakovleva, E.L. (2002). Psikhologiya razvitiya tvorcheskogo potentsiala lichnosti [Psychology of creative personal potential development]. Moscow: Flinta (in Russian).

13. Yakusheva, S.D. (2011). Osnovi pedagogicheskogo masterstva [Basic pedagogical skills]. Moscow: Academy Publishing Centre (in Russian). 